Adamchuk, V., Shchepotina, N., Kostiukevych, V., Vozniuk, T., Kulchytska, I., Didyk, T., \& Poliak, V. (2021). Technological Aspects of Introduction of 8-Week Model at the Phase of Direct Training for Competitions of Highly Qualified Multi-Athletes in Track-And-

Field Athletics. Teoriâ ta Metodika Fizičnogo Vihovannâ, 21(3), 200-210. https://doi.org/10.17309/tmfv.2021.3.03

ISSN 1993-7989 (print). ISSN 1993-7997 (online). ISSN-L 1993-7989

ORIGINAL SCIENTIFIC ARTICLE

\title{
TECHNOLOGICAL ASPECTS OF INTRODUCTION OF 8-WEEK MODEL AT THE PHASE OF DIRECT TRAINING FOR COMPETITIONS OF HIGHLY QUALIFIED MULTI-SPORT ATHLETES IN TRACK-AND-FIELD ATHLETICS
}

\author{
Vadym Adamchuk ${ }^{1 \mathrm{ABCDE}}$, Natalia Shchepotina ${ }^{1 \mathrm{ABCDE}}$, Viktor Kostiukevych ${ }^{1 \mathrm{ABCDE}}$, \\ Tetiana Vozniuk $^{1 \mathrm{ABCDE}}$, Iryna Kulchytska ${ }^{1 \mathrm{BCDE}}$, Tetiana Didyk ${ }^{1 B C D E}$, Vadym Poliak ${ }^{1 B C D E}$ \\ ${ }^{1}$ Vinnytsia Mykhailo Kotsiubynskyi State Pedagogical University \\ Authors' Contribution: A - Study design; B - Data collection; C - Statistical analysis; D - Manuscript Preparation; E - Funds Collection
}

Corresponding Author: Viktor Kostiukevych, E-mail: kostykevich.vik@gmail.com

Accepted for Publication: August 12, 2021

Published: September 25, 2021

DOI: 10.17309/tmfv.2021.3.03

\begin{abstract}
The purpose of study was to develop and to substantiate experimentally the efficiency of the 8-week model of the stage of direct training for main competitions of highly qualified multi-sport athletes in track-and-field athletics. Material and Methodology. 5 highly qualified multi-sport athletes having a sports qualification of the Master of Sports of Ukraine took part in the pedagogical experiment. The average age of the participants was $25.2 \pm 1.79$ years. The technological basis for introduction of combined events competitions of track-and-field athletes into the requirements of the 8-week model of the phase of direct training for main competitions was constituted by: an algorithm of the individual program for training multi-sport athletes for competitions, which reflects the consistency of actions for the purpose of preparing the athletes to perform given tasks; programming of the training process, which shows the directions of performance of tasks during specific mesocycles while taking into account the feasibility of the development of components of technical and physical preparedness and types of combined events competitions in track-and-field athletics; structuring the process of straining and recovery, which determines the permissible levels and intensity of training loads during separate sessions and microcycles.

Results. We reduced the magnitude of training loads (up to $3233 \mathrm{~min}$ ) and increased their intensity (up to 6.51 points-min-1) during the forming experiment at the phase of direct training for competitions, which allowed to achieve peak sports form and evoke additional resources in the organism of athletes.

The introduction of the developed 8-week model of the direct training stage contributed to a statistically significant improvement in the indicators of physical preparedness of the studied multi-sport athletes in running tests by 2.3$3.1 \%$, while it made $4.4-4.9 \%$ in the tests representing speed and strength qualities and $4.5-4.9 \%$ in strength control exercises $(\mathrm{p}<0.05)$. The improvement of the results of most disciplines in the range of $1.7-5.3 \%(\mathrm{p}<0.05)$ confirms the efficiency of the developed 8-week model of the phase of direct training.

Conclusions. Solution of specific tasks during final weeks before the main starts requires the establishment of optimum volumes of training work and load dynamics, combining training sessions with training loads of various orientation and magnitude, using rest and recovery means as a whole complex, ensuring operative and current control over the course of recovery and adaptation processes. Taking the aforementioned problems into account, we have developed an 8-week model at the phase of direct training for competitions, in which three mesocycles were determined with strictly defined tasks and corresponding training content.

Keywords: track-and-field, combined events, decathlon, the phase of direct training, competitions, model, programming, training process.
\end{abstract}

\section{Introduction}

Modern system of training in track-and-field athletics is at the stage of constant development and is characterized by

(C) Adamchuk, V., Shchepotina, N., Kostiukevych, V., Vozniuk, T., Kulchytska, I., Didyk, T., Poliak, V., 2021. a variety of competitions of a significant magnitude as well as financial and rating incentives. It puts heavy demands on the sports results, however there is no further possibility of their improvement on account of the increase in the volume and intensity of training and competitive loads in athletes and it may cause pathological changes in their organism 
(Platonov, 2013; Kozina, Sobko, Bazulyuk et al., 2015; Drachuk, Bohuslavska, Pityn et al., 2018). The existing problem was first addressed in the 60 s of the 20 th century by the prominent Australian specialist F. Carlyle and the soviet specialist L.P. Matveev who established that no more than 25\% of track-and-field athletes could show their best results at the main competitions and other athletes demonstrated their best results at other competitions which often were of minor importance. Under these conditions, participation in competitions with maximum training load started losing sense due to fact that athletes often had to perform in a situation of physical and psychological load (Matveev, 2010).

In view of the above, optimization of training influences at the stage of direct training in order to bring athletes into their optimal sports form for main competitions in order to demonstrate their best results (Dobrynskaya, Kozlova, 2013; Kozlova, Wei, Kozlov, 2020). A variety of significant differences in training of athletes who specialize in certain types of track-and-field athletics complicate the resolution of the mentioned problem in combined track-and-field events. These differences consist in the necessity of daily improvement in three or more types of decathlon under conditions of strict time limitations, a variety of motor coordination, high energy consumption (Zwols, Sierksma, 2009; Bilić, Balić, 2015; Adamczyk, Olszewska, Boguszewski et al., 2016).

The phase of direct preparation for main competitions of the year by its essence changed the long-existing term "narrowing", i.e. tapering (Mujika, Padilla, 2003; Thomas, Busso, 2005; Leonard, 2008). Two models of the phase of direct training for main competitions are used in the modern world sports practice: 5-week West-European and 8-week East-European model. 5-week model includes a control and a preparatory mesocycle with intense load which exceeds previous intense loads by $1015 \%$ in order to mobilize concealed energy resources and achieve an adaptation jump as well as recovery mesocycle ("narrowing") (Platonov, 2013).

The disadvantage of the 5-week model is the lack of special preparation for loads and its limitation only by recovery measures in the pre-competitive mesocycle. These disadvantages were eliminated in the improved 8 -week model which includes a two-week basic mesocycle, three-week control and preparatory mesocycle and three-week pre-competitive mesocycle. The advantages of the 8 -week phase consist in the gradual preparation of the athlete during basic mesocycle and combining special work of integral character with recovery measures in the final pre-competitive mesocycle (Matveev, 2010; Platonov, 2013). Main principles serving as basis for this variant are fundamental and after a minor correction may be successfully used in the majority of sports (Platonov, 2013).

Despite a relatively short duration, the phase of direct training for important competitions, and namely its final competitive mesocycle, plays a significant role in achieving the final result of the long-term work as well as successful participation in competitions (Nedoshchak, Suhinin, 2013). Simultaneously, until now, 8-week scheme of organization of direct training for main competitions has not been used in the combined events competitions in track-and-field athletics. It is primarily connected to the impossibility of conducting loads and simultaneously using several competitive disciplines of combined events competitions during a training session.
Some studies (Dobrynskaya, Kozlova, 2013) have proposed to pay attention to the development of disciplines of combined events competitions, which an athlete displays a greater propensity for, and have determined the types of group models of competitive activity. It brought the scientists much closer to resolving the problem, however, the lack of comprehensive targeted programming of the phase of direct training for main competitions of the year and reliable methods for controlling individual marginal level of physical load do not allow the athletes to show their best results at the main competitions.

In view of the above, and also taking into account the effectiveness and prospects of using the modelling and programming methods in the process of athlete training which was underlined many times in the works by Kutek, Akhmetov, Vovchenko et al. (2018), Khudolii (2019), Kostiukevych, Lazarenko, Shchepotina et al. (2019) and other experts, we consider to be well-timed the development of 8-week model of the phase of direct training for main competitions of highly qualified multi- athletes in track-and-field athletics and its application on practice.

Study hypothesis: it is foreseen that the development of the 8-week model of the phase of direct training will contribute to the more efficient training of highly qualified multi-athletes in track-and-field athletics, will allow them to achieve their peak sports form and evoke additional reserves in the organism of athletes.

The purpose of study was to develop and to substantiate experimentally the efficiency of the 8-week model of the stage of direct training for main competitions of highly qualified multi-athletes in track-and-field athletics.

\section{Material and methodology}

\section{Study participants}

5 highly qualified multi-athletes having a sports qualification of the Master of Sports of Ukraine took part in the pedagogical experiment. Average age of participants made up 25.2 \pm 1.79 years. The study was approved by ethics committee of Vinnytsia State Pedagogical University named after Mykhailo Kotsiubynskyi and all the procedures were in compliance with the Helsinki Convention. The participants gave informed consent for participation in the experiment.

\section{Study organization}

The study was conducted from 2018 to 2020. A scheme of consecutive pedagogical experiment was used. In the course of the ascertaining experiment (2018-2019), pedagogical supervision of training process was performed along with time-keeping of the training work. It allowed to determine the volume of training loads and their division into different types of training of multi-athletes.

Recording the nature and duration of exercises and heart rate of multi-athletes on special forms while performing such exercises using Polar RS800CX heart rate monitor allowed to determine the coefficient of the value load (CVL) using the method by V.A. Sorvanov (Godik, 2006). CVL was calculated as a product of exercise duration and its intensity in points, depending on the heart rate (Kostiukevich, Stasiuk, Shchepotina et al., 2017): exercise intensity with a heart 
rate of $114 \mathrm{bpm}$ was assessed as 1 point; $120 \mathrm{bpm}-2$ points; $126 \mathrm{bpm}-3$ points; $132 \mathrm{bpm}-4$ points; $138 \mathrm{bpm}-5$ points; 144 bpm - 6 points; 150 bpm - 7 points; 156 bpm - 8 points; 162 bpm - 10 points; 168 bpm - 12 points; 174 bpm 14 points; $180 \mathrm{bpm}$ - 17 points; $186 \mathrm{bpm}$ - 21 points; 192 bpm - 25 points; $198 \mathrm{bpm}-33$ points (CVL, points). Load intensity using the coefficient of training load intensity (CItl) was determined as a ratio between CVL and the duration of a training session in minutes $\left(\mathrm{CI}_{\mathrm{t}}\right.$, point $\left.\cdot \mathrm{min}^{-1}\right)$.

Pedagogical testing was performed in order to determine the level of physical preparedness of multi-athletes using the following test exercises:

- $30 \mathrm{~m}$ run from the spot - assessment of speed abilities: testing participant got on the track at a distance of 10-15 meters from the start of a 30-meter distance and started running with a maximum speed by himself; time countdown began after crossing the start line of the 30-meter distance. The best time out of two attempts was recorded, up to within 0,01 seconds. Period of rest between attempts made up 3-5 minutes.

- $60 \mathrm{~m}$ run from high start: testing participant got behind the start line in a high start position; he had to run the given distance after a signal. The best time out of two attempts was recorded, up to within 0.01 seconds. Period of rest between attempts made up 3-5 minutes.

- $\quad 200 \mathrm{~m}$ run and $200 \mathrm{~m}$ run after 1 minute of rest - speed endurance assessment: testing participant started running from high start from the $40 \mathrm{~m}$ run mark; an athlete had to run 200 meters with a maximum speed; then the athlete had a 1 minute rest, then got behind the starting line from a high position and ran another 200 meters. Testing result constituted total time for running two distances. Test was performed once;

- $\quad$ triple long jump from the spot - assessment of speed and strength qualities: a take-off line was marked on the track near the jumping pit, jump length was recorded starting from it; testing participant stood with his toes near the line and performed 3 consecutive jumps, pushing alternately with one leg and then with another, the last jump was performed into the landing pit. Jump length was measured from the take-off line before touching the surface of the jumping pit with heels. The best result out of three attempts was recorded;

- two-handed throw of the shot from below - assessment of speed and strength qualities: the participant holding the shot with two hands stands facing the direction of throwing; feet are shoulder width apart, front part of the foot is on the segment; the shot is thrown from below to the front. The best result out of three attempts was recorded;

- squats with a barbell on shoulders - assessment of strength qualities: the exercise was performed from the initial position of the bar on stands; the athlete approached the stands and took the barbell off putting in on his shoulders from a squatting position. After making a step back, the athlete assumed a position before squatting, then performed a squat and stood back up into the initial position. The athlete returned the barbell back onto the stands with the assistance of the helper. The 1st squat attempt with a maximum weight for each athlete was recorded;
- $\quad$ lifting the barbell onto the chest into a half-squat assessment of strength qualities: exercise was performed from the starting position when the barbell was on the platform; then the athlete took the initial position with his legs at shoulder width, with the bar being as close as possible to his ankles, with his feet pressed against the floor, a straight back and knees bent at approximately $45^{\circ}$. From this position the athlete lifted the bar onto the chest in a half squat. Lifting of the barbell with a maximum weight per 1 rep was recorded.

Pedagogical testing was performed at the beginning and at the end of the phase of direct preparation for competitions during shock microcycles in the process of performing main training work.

Main purpose of the forming experiment (years 20192020) was to develop the programs of structural units of the training process (training sessions, microcycles, mesocycles, phase of direct training for main competitions) and experimental substantiation of the programming and organization of the training process of highly qualified all-round trackand-field athletes.

Technological basis for introduction of combined events competitions of track-and-field athletes into the requirements of 8-week model of the phase of direct training for main competitions was constituted by: an algorithm of individual program for training multi-athletes for competitions which reflects the consistency of actions for the purpose of preparing the athletes to perform given tasks; programming of training process which shows the directions of performance of tasks during specific mesocycles while taking into account the feasibility of the development of components of technical and physical preparedness and types of combined events competitions in track-and-field athletics; structuring the process of straining and recovery which determines the permissible levels and intensity of training loads during separate sessions and microcycles.

The development of an algorithm for creating individual programs included the following sequence of actions:

- assessing the preparedness of athletes for performing the tasks at the phase of direct readiness for main competitions of the year;

- in the determination of direct disciplines with a propensity for development and referral of athletes to the corresponding type of competitive activity;

- construction of the structure of individual program at the phase of direct training for competitions.

The results of indicators of physical preparedness of highly qualified multi- athletes at the phase of direct training for competitions allowed to determine the preparedness of athletes for performing the tasks at the phase of direct training for competitions as well as to conduct a comparative analysis with model characteristics and a result of 8100 points (World Championship norm) as proposed by the authors (Kupchinov, 1998; Cherepyakin, 2014).

According to the data received by us in the process of pedagogical testing, one can note model indicators which are higher than the indicators of speed qualities $(60 \mathrm{~m}$ run $6.83 \pm 0.09$ compared to $7.06 \mathrm{~s}$ ); lag of indicators in the triple jump $-8.94 \pm 0.23$ compared to $9.51 \mathrm{~m}$ and prevalence of results in throwing the shot with two hands from below $15.57 \pm 0.27$ compared to $15.12 \mathrm{~m}$. 
The results of decathlon competition at the phase of the ascertaining experiment allow to distinguish the existing successful disciplines in each of the athletes and the disciplines in which the lagging is observed. The analysis of competitive activity allowed to include three athletes into the second type of group models of competitive activity (speed and strength) and two athletes to the third type (speed). It also allowed to predict the increase in the success during competitions in the $100 \mathrm{~m}$ run, long jump, $400 \mathrm{~m}$ run, $110 \mathrm{~m}$ run with hurdles and to use the respective means of training sessions during mesocycles of the 8-week model of the stage of direct training for main competitions of the year.

The approach used for programming the training process in athletes foresaw the program of training sessions, microcycles, mesocycles; the fulfilment of models of the training programme; assessment of the training effect; correction of the training programme; repeated assessment of the training effect. The scheme of construction of the individual program of the phase of direct training for main competitions of multi-athletes consists of four blocks - determination of purpose, targeted tasks, general stock of training means, model characteristics of physical preparedness (fig. 1).

8 -week model of the phase of direct training for main competitions of the year was used in the research.
Control and preparatory mesocycle was started in 5-6 days after active rest. The mesocycle foresaw the performance of a large volume of work directed towards the development of speed, speed and strength qualities, endurance. Over the first days, the load gradually grew which allowed the athletes to adapt to the loads during the next mesocycle. Intense work regimen was maintained for 7-8 days and then the load was gradually decreased and the cycle ended with a rest day. The peculiarity of the control and preparatory mesocycle consisted in the use of dominant technical and physical qualities and competitive disciplines in the training process.

Pre-competition mesocycle foresaw the creation of conditions for forming a delayed training effect and its full implementation in the competitions. During the mesocycle, the main task consisted in the achievement of the peak of supercompensation by ensuring maximum recovery after loads on the background of the limited training regimen and the use of recovery means.

Introductory, shock and pre-competition microcycles, which became part of control, preparatory and pre-competition mesocycles, were used for programming the training process of highly qualified multi-athletes during the phase of direct training for main competitions

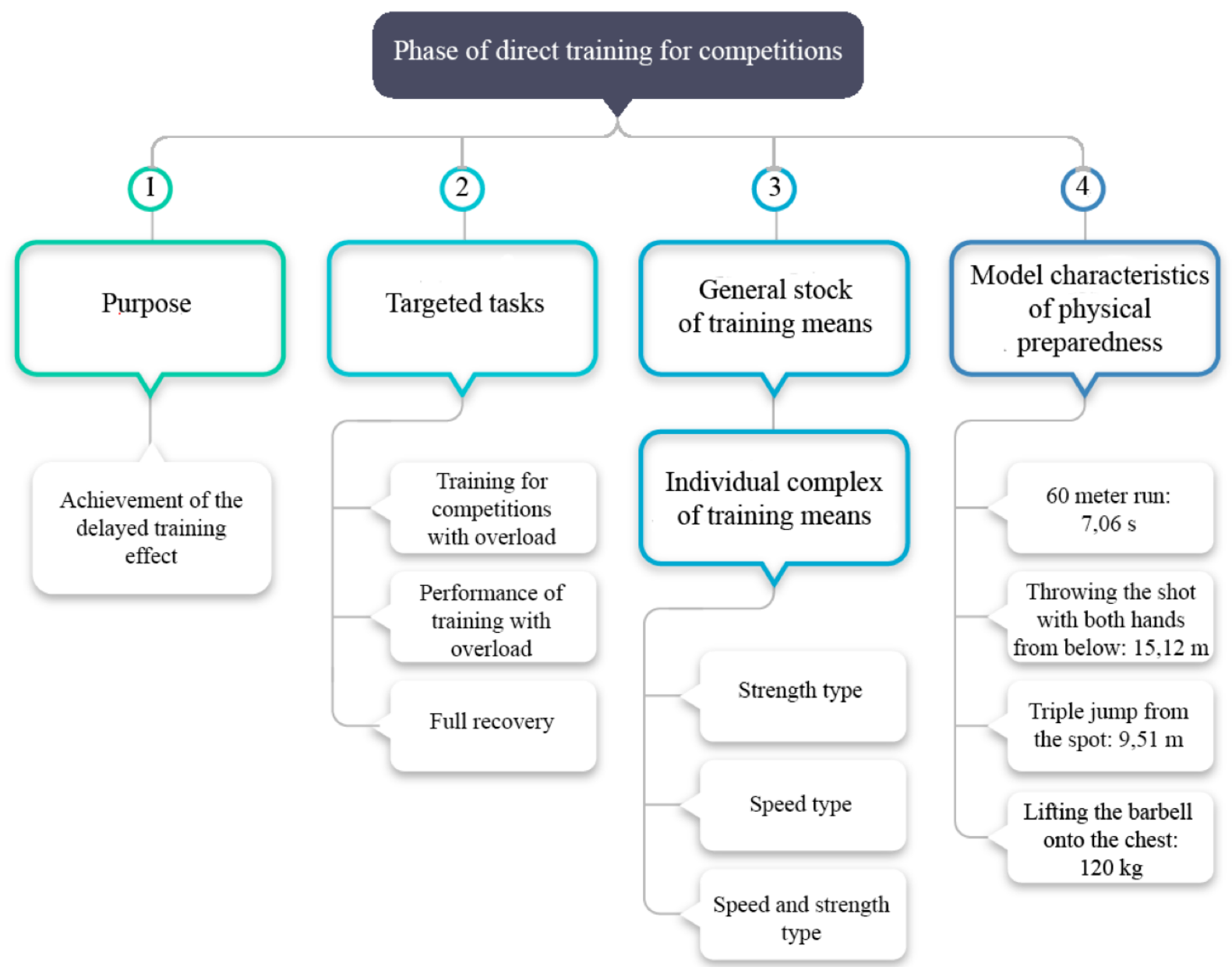

Fig. 1. Scheme of construction of the individual program at the phase of direct training for main competitions of the year 
Table 1. Program of 7-day introductory microcycles of direct training for competitions

\begin{tabular}{|c|c|c|c|c|c|c|c|}
\hline \multirow{2}{*}{ Types of training } & \multicolumn{7}{|c|}{ Days of the microcycle } \\
\hline & $1 \mathrm{st}$ & 2nd & 3rd & 4th & 5 th & 6th & 7 th \\
\hline $\begin{array}{l}\text { General physical training } \\
\text { (GPT) }\end{array}$ & GPT $1.1(\mathrm{a})-20^{4}$ & GPT $1.1(\mathrm{a})-20^{4}$ & GPT $1.1(\mathrm{a})-20^{4}$ & - & GPT $1.1(\mathrm{a})-20^{4}$ & GPT $1.1(\mathrm{a})-20^{4}$ & - \\
\hline $\begin{array}{l}\text { Special physical } \\
\text { preparation } \\
(\mathrm{P}, \mathrm{S}, \mathrm{SP}, \mathrm{E})\end{array}$ & $\begin{array}{c}\text { P-1.4(a) }-5^{5} \\
\text { P-1.5(a) }-7^{5} \\
\text { P-1.25 }-3^{4}\end{array}$ & S-1.6(a) $-10^{10}$ & - & - & - & S- $1.12-8^{13}$ & - \\
\hline $\begin{array}{l}\text { Technical preparation } \\
\text { (TP) }\end{array}$ & $\begin{array}{l}\text { TP-3.5 }-12^{7} \\
\text { TP-3.7 }-15^{8} \\
\text { TP-1.3 - } 3^{4} \\
\text { TP-7.4 }-4^{4}\end{array}$ & $\begin{array}{l}\text { TP-5.1 - } 5^{4} \\
\text { TP-5.2- } 15^{5}\end{array}$ & $\begin{array}{l}\text { TP- } 1.14-20^{12} \\
\text { TP-2.4 }-20^{5}\end{array}$ & - & $\begin{array}{c}\text { TP-4.6-35 } \\
\text { TP-5.1(b) }-5^{4} \\
\text { TP-5.2(b) }-10^{5}\end{array}$ & - & - \\
\hline Competitions & - & - & - & - & - & - & - \\
\hline $\begin{array}{l}\sum \text { of the training work, } \\
\text { min }\end{array}$ & 69 & 50 & 60 & - & 70 & 28 & - \\
\hline CVL, points & 384 & 275 & 440 & - & 465 & 184 & - \\
\hline CItl, points $\cdot \min -1$ & 5.57 & 5.50 & 7.33 & - & 6.64 & 6,57 & - \\
\hline
\end{tabular}

Remarks: record of the exercise TP-3.5 - 127: TP-3.5 - code of the training exercise; 127 - duration of exercise in minutes (12) and intensity of exercise in points (7) by Sorvanov; TP - special technical preparation: TP-1 - hurdling; TP-2 - high jumps; TP-3 - long jumps; TP-4 - pole vaulting; TP-5 - shot throwing; TP-7 - spear throwing; P - strength training; S - special speed training; SP speed and strength training, E - general endurance; S-1 - speed endurance; GPT - general technical and physical training; CVL value load coefficient; $\mathrm{CI}_{\mathrm{tl}}$ - coefficient of intensity of the training load

Table 2. Program of 7-day shock microcycle at the phase of direct training for competitions (speed and strength type)

\begin{tabular}{|c|c|c|c|c|c|c|c|}
\hline \multirow{2}{*}{ Types of training } & \multicolumn{7}{|c|}{ Days of the microcycle } \\
\hline & 1st & 2nd & 3rd & 4th & 5 th & 6th & 7 th \\
\hline $\begin{array}{l}\text { General physical } \\
\text { training (GPT) }\end{array}$ & GPT $1.1(\mathrm{a})-25^{4}$ & GPT $1.1(\mathrm{a})-25^{4}$ & GPT 1.1(a) $-25^{4}$ & - & GPT 1.1(a) $-25^{4}$ & $\begin{array}{c}\text { GPT } 1.1(\mathrm{a})-25^{4} \\
\text { GPT } 1.3-18^{5}\end{array}$ & - \\
\hline $\begin{array}{l}\text { Special physical } \\
\text { preparation } \\
(\mathrm{P}, \mathrm{S}, \mathrm{SP}, \mathrm{E})\end{array}$ & SP $1.7-20^{6}$ & $\begin{array}{l}\text { P } 1.4(\mathrm{a})-15^{4} \\
\mathrm{P} 1.5(\mathrm{a})-15^{5}\end{array}$ & S $1.6(a)-15^{6}$ & - & - & $\begin{array}{c}\text { P } 1.2-30^{6} \\
\text { SP- } 1.5-25^{10}\end{array}$ & - \\
\hline $\begin{array}{l}\text { Technical preparation } \\
\text { (TP) }\end{array}$ & $\begin{array}{c}\text { TP- } 1.14-28^{13} \\
\text { TP-6.1- } 10^{5} \\
\text { TP-6.2- } 22^{6}\end{array}$ & $\begin{array}{l}\text { TP-4.3(a) }-40^{7} \\
\text { TP-7.1(b) }-10^{4} \\
\text { TP-7.2(b) }-15^{5}\end{array}$ & $\begin{array}{l}\text { TP-3.4- } 10^{7} \\
\text { TP-3.5- } 15^{7} \\
\text { TP-3.7- } 8^{14}\end{array}$ & - & $\begin{array}{c}\text { TP-1.5(a) }-30^{8} \\
\text { TP-2.4 }-30^{5} \\
\text { TP-5.6-15 }\end{array}$ & $\begin{array}{l}\text { TP-5.1(b) }-5^{4} \\
\text { TP-5.2(b) }-15^{5}\end{array}$ & \\
\hline Competitions & - & - & - & - & $30^{10}$ & $40^{10}$ & - \\
\hline$\sum$ of work, min & 105 & 120 & 73 & - & 130 & 158 & - \\
\hline CVL, points & 766 & 655 & 502 & - & 890 & 1025 & - \\
\hline $\mathrm{CI}_{\mathrm{t}}$, points $\cdot \mathrm{min}^{-1}$ & 7.30 & 5.45 & 6.87 & - & 6.85 & 7.32 & - \\
\hline
\end{tabular}

Remarks: record of the exercise SP-1.7 - 206: SP-1.7 - code of the training exercise; 206 - duration of exercise in minutes (20) and intensity of exercise in points (6) by Sorvanov; TP - special technical preparation: TP-1 - hurdling; TP-2 - high jumps; TP-3 long jumps; TP-4 - pole vaulting; TP-5 - shot throwing; TP-7 - spear throwing; P - strength training; $\mathrm{S}$ - special speed training; $\mathrm{SP}$ - speed and strength training; GPT - general technical and physical training; CVL - value load coefficient; $\mathrm{CI}_{\mathrm{tl}}-\mathrm{coefficient} \mathrm{of}$ intensity of the training load

During the introductory microcycles (table 1), main attention was given to the increase of the training load with the inclusion of anaerobic-alactate energy system for the purpose of achieving optimum level of preparedness for subsequent shock loads. Also, during this microcycle multi-athletes performed control runs, jumps or throws, depending on the dominant type in competitive disciplines.

The task of 7-day shock microcycles (table 2) consists in the creation of incentives for forming a marked delayed training effect on account of intense training with the use of concealed inner resources for increasing the adaptation to significant training loads. The peculiarity of shock microcycles is the specificity of work of multi-athletes of dif- ferent types (roughly divisible into "speed" and "speed and strength"). Thus, the programming of preparatory microcycles was performed separately for athletes who belonged to a certain type. During shock microcycles the athletes took part in the preparatory and control competitions.

Recovery microcycles (table 3 ) were planned after taking part in control competitions and after shock microcycles. The duration of training sessions and value load grew from the first up to the last day of the microcycle. The content of training sessions included general and preparatory exercises for primarily developing general endurance and strength. Special technical training exercises were added only on the 6th day of the microcycle. The intensity of load during the recovery microcycle had a wavy dynamics. 
Table 3. Program of the 7-day recovery microcycle at the phase of direct training for competitions

\begin{tabular}{|c|c|c|c|c|c|c|c|}
\hline \multirow{2}{*}{ Training sections } & \multicolumn{7}{|c|}{ Days of the microcycle } \\
\hline & 1 st & 2nd & 3 rd & 4th & 5th & 6th & 7th \\
\hline $\begin{array}{l}\text { General physical training } \\
\text { (GPT) }\end{array}$ & GPT $1.1(\mathrm{a})-20^{5}$ & - & GPT $1.1(\mathrm{a})-20^{5}$ & - & GPT $1.1(\mathrm{a})-20^{5}$ & GPT $1.1(\mathrm{a})-20^{5}$ & - \\
\hline $\begin{array}{l}\text { Special physical } \\
\text { preparation (P, S, SP, E) }\end{array}$ & E- $1.1-15^{6}$ & - & $\begin{array}{l}\text { E- } 1.1-21^{5} \\
\text { P- } 1.7-5^{4}\end{array}$ & - & $\begin{array}{l}\text { SP- } 1.7-15^{5} \\
\text { S- } 1-10^{14}\end{array}$ & P-1.4(b) $-15^{5}$ & - \\
\hline $\begin{array}{l}\text { Technical preparation } \\
\text { (TP) }\end{array}$ & - & - & - & - & - & TP-4.3(a) $-25^{7}$ & - \\
\hline Competitions & - & - & - & - & - & - & - \\
\hline $\begin{array}{l}\Sigma \text { of the training work, } \\
\min \end{array}$ & 35 & - & 46 & - & 45 & 60 & - \\
\hline CVL, points & 190 & - & 225 & - & 315 & 350 & - \\
\hline $\mathrm{CI}_{\mathrm{t}}$, points $\cdot \mathrm{min}^{-1}$ & 5.43 & - & 4.89 & - & 7.00 & 5.83 & - \\
\hline
\end{tabular}

Remarks: record of the exercise E-1.1 - 156: E-1.1 - code of the training exercise; 156 - duration of exercise in minutes (15) and intensity of exercise in points (7) by Sorvanov; TP - special technical preparation: TP-4 - pole vaulting; P - strength training; SP - speed and strength training, E - general endurance; S-1 - speed endurance; PT - general technical and physical training; CVL - value load coefficient; $\mathrm{CI}_{\mathrm{tl}}$ - coefficient of intensity of the training load

\section{Statistical analysis}

Mathematical processing of results was conducted using the package "Data analysis" of the software MS Office Excel (Byshevets, Denysova, Shynkaruk et al, 2019). Descriptive statistics was used which foresaw the determination of a means (X) and standard deviation (S). Statistical reliability in the difference of results of pedagogical testing and competitive activity of multi-athletes at the beginning and at the end of the ascertaining and forming stages of pedagogical experiment was determined by the nonparametric Wilcoxon T-test. Differences between groups were considered to be statistically reliable at $\mathrm{p}<0.05$.

\section{Results}

On the basis of the obtained data of the training programs of microcycles for further substantiation of results, we have managed to generalize the load parameters which were used at the stages of direct training for competitions in the spring and summer annual macrocycles during the ascertaining and forming experiment (fig. 2).

Based on the data of fig. 2, we managed to demonstrate that during the forming experiment at the phase of direct training for competitions we reduced the magnitude of training loads (up to $3233 \mathrm{~min}$ ) and increased their intensity (up to 6.51 points.min-1) which allowed to achieve peak
Fig. 2. Parameters of loads at the phase of direct training for competitions (spring and summer cycle) of highly-qualified multi-athletes during the ascertaining (AE) and forming (FE) experiment:

- value load coefficient; - technical preparation; - - physical training; - participation in competitions; - testing; $\longmapsto$ - load intensity coefficient

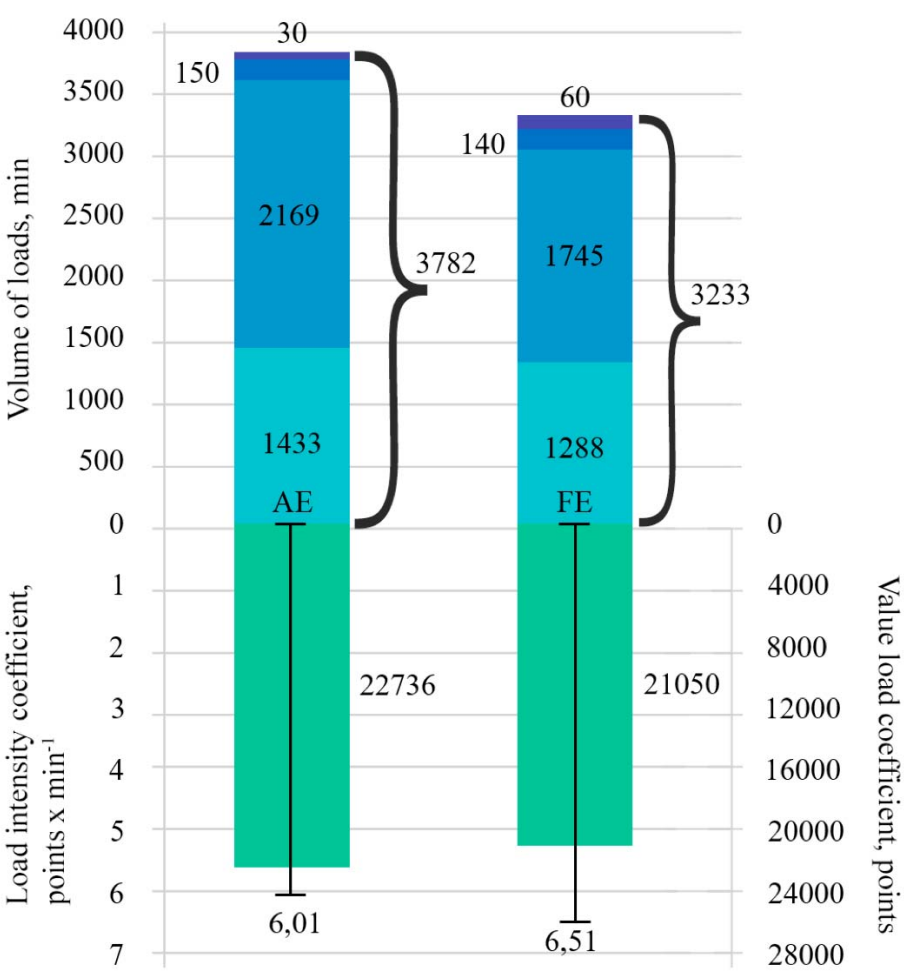


Table 4. Indicators of physical preparedness of decathletes at the phases of the ascertaining and forming experiments

\begin{tabular}{|c|c|c|c|c|c|c|c|c|c|}
\hline \multirow{3}{*}{ Test } & \multirow{3}{*}{ Phase } & \multicolumn{8}{|c|}{ Statistical indicators } \\
\hline & & \multicolumn{2}{|c|}{ Output data } & \multicolumn{2}{|c|}{ Final data } & \multicolumn{2}{|c|}{ Changes } & & \multirow{2}{*}{$\mathrm{p}$} \\
\hline & & $\mathbf{X}$ & $\mathrm{S}$ & $\mathrm{X}$ & $S$ & Absolute & $\%$ & & \\
\hline \multirow{2}{*}{$30 \mathrm{~m}$ run from the spot, $\mathrm{s}$} & $\mathrm{AE}$ & 2.96 & 0.08 & 2.95 & 0.04 & 0.01 & 0.4 & 2 & $>0.05$ \\
\hline & $\mathrm{FE}$ & 2.89 & 0.07 & 2.80 & 0.07 & 0.09 & 3.1 & 0 & $<0.05$ \\
\hline \multirow{2}{*}{$60 \mathrm{~m}$ run from high start, $\mathrm{s}$} & $\mathrm{AE}$ & 6.92 & 0.05 & 6.85 & 0.09 & 0.07 & 1.0 & 1 & $>0.05$ \\
\hline & FE & 6.83 & 0.09 & 6.67 & 0.17 & 0.16 & 2.3 & 0 & $<0.05$ \\
\hline \multirow{2}{*}{$\begin{array}{l}200 \mathrm{~m} \text { and } 200 \mathrm{~m} \text { run after } 1 \text { minute of } \\
\text { rest, } \mathrm{s}\end{array}$} & $\mathrm{AE}$ & 49.95 & 1.15 & 49.89 & 1.00 & 0.06 & 0.1 & 2 & $>0.05$ \\
\hline & $\mathrm{FE}$ & 49.70 & 0.64 & 48.33 & 0.52 & 1.37 & 2.8 & 0 & $<0.05$ \\
\hline \multirow{2}{*}{ Triple jump from the sport, $\mathrm{m}$} & $\mathrm{AE}$ & 8.92 & 0.23 & 9.04 & 0.21 & 0.12 & 1.3 & 1 & $>0.05$ \\
\hline & $\mathrm{FE}$ & 8.94 & 0.23 & 9.38 & 0.30 & 0.44 & 4.9 & 0 & $<0.05$ \\
\hline \multirow{2}{*}{$\begin{array}{l}\text { Throwing the shot with two hands from } \\
\text { below, } \mathrm{m}\end{array}$} & $\mathrm{AE}$ & 15.25 & 0.43 & 15.51 & 0.58 & 0.26 & 1.7 & 2 & $>0.05$ \\
\hline & $\mathrm{FE}$ & 15.57 & 0.27 & 16.26 & 0.64 & 0.69 & 4.4 & 0 & $<0.05$ \\
\hline \multirow{2}{*}{ Squats with a barbell, kg } & $\mathrm{AE}$ & 140 & 6.44 & 147 & 8.58 & 7 & 5.0 & 0 & $<0.05$ \\
\hline & $\mathrm{FE}$ & 152 & 6.44 & 160 & 10.73 & 8 & 5.2 & 0 & $<0.05$ \\
\hline \multirow{2}{*}{ Lifting the barbell onto the chest, $\mathrm{kg}$} & $\mathrm{AE}$ & 102 & 6.44 & 106 & 8.58 & 4 & 3.9 & 1 & $>0.05$ \\
\hline & FE & 112 & 4.29 & 115 & 10.73 & 3 & 4.5 & 0 & $<0.05$ \\
\hline
\end{tabular}

Remarks: AE - ascertaining experiment; FE - forming experiment

Table 5. Results of competitive activity of athletes at the stages of the ascertaining and formation experiments

\begin{tabular}{|c|c|c|c|c|c|c|c|c|}
\hline \multirow{3}{*}{ Competitive type of decathlon } & \multicolumn{8}{|c|}{ Statistical indicators } \\
\hline & \multicolumn{2}{|c|}{$\mathrm{AE}$} & \multicolumn{2}{|c|}{ FE } & \multicolumn{2}{|c|}{ Changes } & \multirow{2}{*}{$\mathbf{T}$} & \multirow{2}{*}{$\mathbf{p}$} \\
\hline & $\mathrm{X}$ & $S$ & $\mathrm{X}$ & $S$ & Abs. & $\%$ & & \\
\hline $100 \mathrm{~m}$ run, $\mathrm{s}$ & 11.40 & 0.29 & 11.34 & 0.46 & 0.06 & 0.5 & 1 & $>0.05$ \\
\hline Long jump, $\mathrm{m}$ & 6.92 & 0.71 & 7.07 & 0.42 & 0.15 & 2.2 & 0 & $<0.05$ \\
\hline Shot put, $\mathrm{m}$ & 13.72 & 0.87 & 13.95 & 0.74 & 0.23 & 1.7 & 0 & $<0.05$ \\
\hline High jump, $\mathrm{cm}$ & 192.80 & 7.72 & 197.60 & 9.01 & 4.80 & 2.5 & 0 & $<0.05$ \\
\hline $400 \mathrm{~m}$ run, $\mathrm{s}$ & 51.17 & 1.05 & 51.35 & 1.20 & 0.18 & 0.4 & 2 & $>0.05$ \\
\hline $110 \mathrm{~m}$ hurdles, $\mathrm{m}$ & 15.40 & 0.69 & 15.32 & 0.38 & 0.08 & 0.5 & 1 & $>0.05$ \\
\hline Discus throw, $\mathrm{m}$ & 38.80 & 2.05 & 40.84 & 2.71 & 2.04 & 5.3 & 0 & $<0.05$ \\
\hline Pole vault, $\mathrm{m}$ & 4.30 & 0.25 & 4.44 & 0.19 & 0.14 & 3.3 & 0 & $<0.05$ \\
\hline Javelin throw, $\mathrm{m}$ & 50.66 & 5.64 & 52.28 & 5.23 & 1.62 & 3.2 & 0 & $<0.05$ \\
\hline $1500 \mathrm{~m}$ run, $\min$ & 4.58 & 0.36 & 4.48 & 0.09 & 0.10 & 2.2 & 0 & $<0.05$ \\
\hline Amount of points & 7085.60 & 647.64 & 7332.00 & 326.18 & 246.4 & 3.5 & 0 & $<0.05$ \\
\hline
\end{tabular}

Remarks: AE - ascertaining experiment; FE - forming experiment; Abs. - Absolute Changes

sports form and evoke additional resources in the organism of athletes.

The duration at the phase of direct training for competitions of the second cycle (spring and summer) of the annual training process made 8 weeks. Control and preparatory mesocycle consisted of 7-day introductory, three 7-day shock, 7-day and 4-day recovery microcycles. Pre-competition mesocycles included 7-day and 3-day shock microcycles divided by 7-day recovery microcycle. Athletes also took part in the preparatory and control competitions with a monthly interval. During each microcycle, at the phase of direct training for competitions the training was held once a day and specific tasks were resolved during it. The effectiveness of performance of the program at the phase of direct training for main competitions of the year is demonstrated by the data in table 4 .

Based on the data in table 4, we can state that as a result of performing the developed individual training programs at the phase of direct training for competitions, the athletes ex- perienced significant positive changes in the state of preparedness for participation in main competitions in decathlon. And namely, statistically reliable differences $(p<0.05)$ were achieved in comparison with an ascertaining experiment in all indicators of physical preparedness. Moreover, the increase in the indicators of the running tests made $2.3-3.1 \%$, while it made $4.4-4.9 \%$ in the tests representing speed and strength qualities and 4.5-4.9\% in strength control exercises.

Participation in competitions in the spring and summer seasons also showed an increase of the results of highly qualified athletes in types of decathlon which were included into the pedagogical experiment (table 5).

Summarizing the obtained results of performances of highly qualified athletes at competitions we can state that there was a significant increase in the results regarding the total amount of points in all athletes. The analysed data give sufficient grounds to believe that the influence of the program of training sessions and the program of microcycles at the phase of direct training for competitions allowed the ath- 
letes to achieve their peak sports form and to demonstrate high sports results.

\section{Discussion}

In spite of the existing need to improve the training of highly qualified of multi- athletes, the problem of introduction of 8-week model of the phase of direct training for main competitions into the combined events competitions in track-and-field athletics has not been sufficiently discussed in the special literature. So, the algorithm of construction of individual programs which was developed by us and included the assessment of preparedness of athletes, determination of propensity for corresponding sports disciplines and, specifically, the construction of individual programs at the phase of direct training as well as the approach used for programming structural formations of the training process (training sessions, microcycles, mesocycles) represent a significant contribution to the scientific achievements related to the theoretical and methodical foundations and peculiarities of practical training of multi-athletes (Kenny, Sprevak, Sharp et al., 2005; Dobrynskaya, Kozlova, 2013; Pavlović, Vrcić, Petrović, 2020).

In particular, we associate the improvement of indicators of physical preparedness in multi-athletes with a wellbalanced distribution of work and rest during training sessions, positive influence of all qualitative and quantitative components of training means. Besides, the increase in the test results may be explained by programming the training process in compliance with the principles of overload, supercompensation and specificity, rational distribution of intensity and magnitude of training loads while performing training loads during specific training sessions and microcycle at the phase of direct training for competitions (Bompa, Haff, 2009; Platonov, 2013, 2015).

In such manner, the approaches with respect to modelling (Kostiukevych, Imas, Borysova et al., 2018; Kostiukevych, Shchepotina, Shynkaruk et al., 2019; Kostiukevych, Shchepotina, Vozniuk, 2020) and programming (Kostiukevich, Stasiuk, Shchepotina et al., 2017; Kostiukevych, Lazarenko, Shchepotina et al., 2019) of competitive activity and structural formation of the training process of qualified athletes of team game types of sports during the annual training cycles, which were approved in our previous studies, were also reflected in the practice of training highly qualified multi-athletes (Adamchuk, 2019, 2020). The proposed 8-week model of the phase of direct training for main competitions of the year may be used in the combined events competitions in track-and-field athletics as a reference point and, after respective corrections, it may be also used in the practice of training qualified female and male athletes.

The results of our study confirm the available data regarding the feasibility of targeted and differentiated approach of training efforts in mesocycles at the phase of direct training for main competitions for the purpose of developing priority physical qualities and successful competitive disciplines (Dobrynskaya, Kozlova, 2013; Nedoshchak, Suhinin, 2013), as well as the efficiency of the use of programming in the process of athlete training (Kutek, Akhmetov, Vovchenko et al., 2018; Khudolii, 2019; Kostiukevych, Lazarenko, Shchepotina et al., 2019).

Besides, we have contributed to the existing scientific achievements related to the problem of management of training qualified athletes during combined events competitions in track-and-field athletics (Zwols, Sierksma, 2009; Cherepyakin, 2014; Adamczyk, Olszewska, Boguszewski et al., 2016) as well as to the rational distribution of training loads of highly qualified athletes at the phase of direct training for competitions (Sikorski, 2011; Dobrynskaya, Kozlova, 2013; Kutek, Akhmetov, 2018).

At the same time, it is worth noting that the used innovative approaches do not represent the only solution of existing problems in training multi-athletes in track-andfield athletics for competitions at the high level. Despite significant increase in the opportunities for achieving sports successes while using 8-week model at the phase of direct training for competitions, in which key role belongs to the creation of conditions for maximum delayed training effect by way of physical overloads, the promising capabilities of this model are limited by physiological ability of the human body for increasing physical loads (Wilmore, Costill, Kenney, 2012).

\section{Conclusions}

1. Solution of specific tasks during final weeks before the main starts requires the establishment of optimum volumes of training work and load dynamics, combining training sessions with training loads of various orientation and magnitude, using rest and recovery means as a whole complex, ensuring operative and current control over the course of recovery and adaptation processes. Taking the aforementioned problems into account, we have developed an 8-week model at the phase of direct training for competitions, in which three mesocycles were determined with strictly defined tasks and corresponding training content.

2. The program of the training process at the phase of direct training for main competitions of the year was developed in accordance with fundamental provisions of 8-week model. Fulfilment of the program and structuring training sessions according to the tasks of control, preparatory and pre-competition mesocycles helped to solve the following main tasks: performance of loads for maintenance of the achieved training level; verification and clarification of technical elements; objective control of intensity of training sessions, effectiveness of urgent and delayed recovery; psychological preparation for competitions; providing acting rest before competitions.

3. Statistically reliable improvement of all parameters of physical preparedness in the studied multi-athletes from 2,3 to $5,2 \%$ and the results of the majority of the competitive activity within the limits of $1,7-5,3 \%(p<0,05)$ confirms the efficiency of the developed 8-week model of the phase of direct training for main competitions of highly qualified multi-athletes and the prospects of the use of the programming method in the practice of training of athletes of this type of sports.

\section{Acknowledgements}

The research was carried out within the framework of the plan of the research work of the Department of Theory and Methodology of Sports of Vinnytsia Mykhailo Kotsiubynskyi State Pedagogical University for 2016-2020 “Theoreti$\mathrm{cal}$ and Methodological Foundations of Programming and 
Modeling of the Training Process of Sportsmen of Different Qualifications" (state registration number 0116U005299) and for 2021-2025 "Organizational and methodological principles of programming the training process of gratified and highly gratified athletes" (state registration number 0121U109550).

\section{Conflict of interests}

The authors state that there is no conflict of interests.

\section{References}

Platonov, V.N. (2013). Periodizaciia sportivnoj trenirovki. Obshchaia teoriia i ee prakticheskoe primenenie. Kyiv: Olympic Literature. (in Russian)

Kozina, Zh., Sobko, I., Bazulyuk, T., Ryepko, O., Lachno, O., \& Ilnitskaya, A. (2015). The applyng of the concept of individualizaation in sport. Journal of Physical Education and Sport, 15(2), 172-177.

https://www.doi.org/10.7752/jpes.2015.02027

Drachuk, S., Bohuslavska, V., Pityn, M., Furman, Y., Kostiukevych, V., Gavrylova, N., Salnykova, S., \& Didyk, T. (2018). Energy supply capacity when using different exercise modes for young 17-19-year-old men. Journal of Physical Education and Sport, 18(1), 246-254. https://doi.org/10.7752/jpes.2018.01033

Matveev, L. P. (2010). Obshchaya teoriya sporta i yeye prikladnyye aspekty. 5-ye izd. Moscow: Sov. sport. (in Russian)

Dobrynskaya, N. V, \& Kozlova, E. K. (2013). Modelirovanie sorevnovatel'noj deyatel'nosti kak osnova individualizacii postroeniya mnogoletnej podgotovki $\mathrm{v}$ legkoatleticheskom mnogobor'e (zhenshchiny). Nauka $v$ olimpijskom sporte, 3, 31-37. (in Russian)

Kozlova, E., Wei, W., \& Kozlov, K. (2020). Individual peculiarities of long jump technique of skilled athletes. Journal of Physical Education and Sport, 20, 408-412. https://www.doi.org/10.7752/jpes.2020.s1058

Zwols, Y., \& Sierksma, G. (2009). OR Practice-Training Optimization for the Decathlon. Operations research, 57(4), 812-822. https://doi.org/10.1287/opre.1080.0616

Bilić, M., \& Balić, A. (2015). Types of discipline decathlon functional dependences in relation to age and level of score achievements of the world most successful decathlons. Sport Science, 8(1), 52-56.

Adamczyk, J. G., Olszewska, M., Boguszewski, D., Białoszewski, D., \& Reaburn, P. (2016). Is it possible to create a thermal model of warm-up? Monitoring of the training process in athletic decathlon. Infrared Physics \& Technology, 76, 555-559.

https://doi.org/10.1016/j.infrared.2016.04.017

Mujika, I., \& Padilla, S. (2003). Scientific bases for precompetition tapering strategies. Medicine \& Science in Sports \& Exercise, 35(7), 1182-1187. https://doi.org/10.1249/01.mss.0000074448.73931.11

Thomas, L, \& Busso, T. A. (2005). Theoretical study of taper characteristics to optimise performance. Medicine \& Science in Sports \& Exercise, 37(9), 1615-1621. https://doi.org/10.1249/01.mss.0000177461.94156.4b
Leonard, J. (2008). The training of swimmers. Physiology school. Fort Lauderdale: ASCA, 80-129.

Nedoshchak, V. S, \& Suhinin, V. A. (2013). Organizaciya trenirovochnogo processa na predsorevnovatel'nom etape. Naukovyy chasopys Natsionalnoho pedahohichnoho universytetu imeni M.P. Drahomanova. Seriya № 15: Naukovo-pedahohichni problemy fizychnoyi kultury (fizychna kultura i sport), 12(39), 94-100. (in Russian)

Kutek, T., \& Akhmetov, R. (2018). Improvement of sports training of qualified athletes. Health, Sport, Rehabilitation, 3(2), 44-49. http://doi.org/10.34142/zenodo.1110381

Khudolii, O. (2019). Research Program: Modeling of Young Gymnasts' Training Process. Teoriâ ta Metodika Fizičnogo Vihovannâ, 19(4), 168-178. https://doi.org/10.17309/tmfv.2019.4.02

Kostiukevych, V., Lazarenko, N., Shchepotina, N., Poseletska, K., Stasiuk, V., Shynkaruk, O., Borysova, O., Denysova, L., Potop, V., Vozniuk, T., Dmytrenko, S., Kulchytska, I., Konnova, M., \& Iakovenko, O. (2019). Programming of the training process of qualified football players in the competitive period of the macrocycle. Journal of Physical Education and Sport, 19(6), 2192-2199. https://doi.org/10.7752/jpes.2019.s6329

Godik, M.A. (2006). Fizicheskaya podgotovka futbolistov. Moscow: Terra-Sport, Olimpia Press. (in Russian)

Kupchinov, R. I. (1998). Upravlenie mnogoletnej podgotovkoj sportsmenov mnogoborcev: doct. diss. Minsk. (in Russian)

Cherepyakin, R. S. (2014). Upravlenie podgotovkoj vysokospecializirovannyh desyatiborcev $v$ godichnom cikle na osnove informacionnoj bazy dannyh: kand. diss. Moscow. (in Russian)

Byshevets, N., Denysova, L., Shynkaruk, O., Serhiyenko, K., Usychenko, V., Stepanenko, O., \& Syvash, I. (2019). Using the methods of mathematical statistics in sports and educational research. Journal of Physical Education and Sport, 19(3), 1030-1034. https://www.doi.org/10.7752/jpes.2019.s3148

Kenny, I. C., Sprevak, D., Sharp, C., \& Boreham, C. (2005). Determinants of success in the olympic decathlon: Some statistical evidence. Journal of Quantitative Analysis in Sports, 1(1). https://doi.org/10.2202/1559-0410.1002

Pavlović, R., Vrcić, M., \& Petrović, B. (2020). Athletic decathlon: are there differences between the results of decathlon record-holders and their best personal results? Journal of Physical Education Research, 7(II), 18-26.

Bompa, T. O., \& Haff, G. G. (2009). Periodization: Theory and Methodology of Training. Champaign, IL, USA: Human Kinetics.

Platonov, V.N. (2015). Systema podhotovky sportsmenov v olympyiskom sporte. Obshchaia teoriia i ee prakticheskoe primenenie. Kyiv: Olympic Literature. (in Russian)

Kostiukevych, V., Imas, Ye., Borysova, O., Dutchak, M., Shynkaruk, O., Kogut, I., Voronova, V., Shlonska, O., \& Stasiuk, I. (2018). Modeling of the athletic training process in team sports during an annual macrocycle. Journal of Physical Education and Sport, 18(1), 327-334. https://doi.org/10.7752/jpes.2018.s144

Kostiukevych, V., Shchepotina, N., Shynkaruk, O., Kulchytska, I., Borysova, O., Dutchak, M., Vozniuk, T., Yakovliv, V., 
Denysova, L., Konnova, M., Khurtenko, O., Perepelytsia, O., Polishchuk, V., \& Shevchyk, L. (2019). Training process construction of the qualified volleyball women players in the preparatory period of two-cycle system of the annual training on the basis of model training tasks. Journal of Physical Education and Sport, 19(s2), 427-435. https://www.doi.org/10.7752/jpes.2019.s2063

Kostiukevych, V., Shchepotina, N., \& Vozniuk, T. (2020). Monitoring and Analyzing of the Attacks of the Football Team. Teoriâ ta Metodika Fizičnogo Vihovannâ, 20(2), 68-76. https://doi.org/10.17309/tmfv.2020.2.02

Kostiukevich, V.M., Stasiuk, V.A., Shchepotina, N.Yu., \& Dyachenko, A.A. (2017). Programming of skilled football players training process in the second cycle of specially created training during the year. Physical Education of Students, 21(6), 262-269.

https://doi.org/10.15561/20755279.2017.0602

Adamchuk, V. (2019). Technology of individualization of the training process of the multi-athletes in the field of higher achievements in the preparatory period of the macrocycle. Physical Education, Sport and Health Culture in Modern Society, 4(48), 109-116. https://doi.org/10.29038/2220-7481-2019-04-109-116 (in Ukrainian)

Adamchuk, V. V. (2020). Programming of training classes of highly qualified decathetes at the stage of direct for competition. Fizychna kultura, sport ta zdorovya natsiyi, 9(28), 98-105.

https://doi.org/10.31652/2071-5285-2020-9(28)-98-105 (in Ukrainian)

Kutek, T., Akhmetov, R., Vovchenko, I., Dmitrenko, S., Shaverskyi, V., \& Chernyshenko, T. (2018). Development and application of model characteristics for optimizing the educational and training process of qualified athletes. Journal of Physical Education and Sport, 18(2), 933-936. https://www.doi.org/10.7752/jpes.2018.02138

Sikorski, W. (2011). New approach to preparation of elite judo athletes to main competition. Journal of Combat Sports and Martial Arts, 2(1), 57-60. https://doi.org/10.5604/20815735.1047134

Wilmore, I.H., Costill, D.L., \& Kenney, L.W. (2012). Physiology of sport and exercise. Illinois: Human Kinetics.

\title{
ТЕХНОЛОГІЧНІ АСПЕКТИ ВПРОВАДЖЕННЯ 8-ТИЖНЕВОЇ МОДЕЛІ ЕТАПУ БЕЗПОСЕРЕДНЬОЇ ПІДГОТОВКИ ДО ЗМАГАНЬ ВИСОКОКВАЛІФІКОВАНИХ БАГАТОБОРЦІВ 3 ЛЕГКОЇ АТЛЕТИКИ
}

\author{
Вадим Адамчук ${ }^{1 \mathrm{ABCDE}}$, Наталя Щепотіна ${ }^{1 \mathrm{ABCDE}}$, Віктор Костюкевич $^{1 \mathrm{ABCDE}}$, \\ Тетяна Вознюк ${ }^{1 \mathrm{ABCDE}}$, Ірина Кульчицька ${ }^{1 \mathrm{BCDE}}$, Тетяна Дідик ${ }^{1 \mathrm{BCDE}}$, Вадим Поляк $^{1 \mathrm{BCDE}}$
}

${ }^{1}$ Вінницький державний педагогічний університет імені Михайла Коцюбинського

Авторський вклад: А - дизайн дослідження; В - збір даних; C - статаналіз; D - підготовка рукопису; E - збір коштів

Реферат. Стаття: 11 с., 2 рис., 5 табл., 33 джерел.

Мета дослідження - розробити й експериментально обгрунтувати ефективність 8-тижневої моделі етапу безпосередньої підготовки до головних змагань висококваліфікованих багатоборців з легкої атлетики.

Матеріал і методи. У педагогічному експерименті брали участь 5 висококваліфікованих багатоборців, спортивна кваліфікація яких - Майстер спорту України. Середній вік учасників становив $25,2 \pm 1,79$ років. Технологічну основу 8 -тижневої моделі етапу безпосередньої підготовки до головних змагань складали: алгоритм індивідуальної програми підготовки багатоборців до змагань, що відображає послідовність дій у досягненні готовності до виконання поставлених завдань; програмування тренувального процесу, що демонструє напрями реалізації завдань специфічних мезоциклів з урахуванням доцільності розвитку компонентів технікофізичної підготовленості та видів легкоатлетичного багатоборства; структурування тренувально-відновлювального процесу, що визначає допустимі обсяги й інтенсивність тренувальних навантажень в окремих заняттях і мікроциклах.

Результати. У формувальному експерименті на етапі безпосередньої підготовки до змагань ми зменшили обсяг тренувальних навантажень (до 3233 хв) і збільшили їх інтенсивність (до 6,51 бал·хв ${ }^{-1}$ ), що дало змогу вийти на пік спортивної форми та викликати додаткові резерви в організмі спортсме- нів. Впровадження розробленої 8-тижневої моделі етапу безпосередньої підготовки сприяло статистично достовірному покращенню показників фізичної підготовленості досліджуваних багатоборців у бігових тестах на 2,3-3,1\%, у тестах, що відображали швидкісно-силові якості - на 4,4-4,9\%, у силових контрольних вправах - на 4,5-4,9\% (p < 0,05). Покращення результатів більшості дисциплін змагальної діяльності в межах 1,7-5,3\% ( $<$ 0,05) підтверджує ефективність розробленої 8-тижневої моделі етапу безпосередньої підготовки.

Висновки. Вирішення специфічних завдань у заключні тижні перед головними стартами вимагає встановлення оптимальних обсягів тренувальної роботи та динаміки навантаження, поєднання занять $з$ тренувальними навантаженнями різної спрямованості й величини, використання відпочинку, відновлювальних засобів у вигляді цілісного комплексу, забезпечення оперативного та поточного контролю за перебігом відновлювальних і адаптаційних процесів. 3 урахуванням зазначених проблем, розроблено 8-тижневу модель етапу безпосередньої підготовки до змагань, у якій було виділено три мезоцикли з суворо окресленими завданнями і відповідним їм змістом підготовки.

Ключові слова: легка атлетика, багатоборство, десятиборство, етап безпосередньої підготовки, змагання, модель, програмування, тренувальний процес. 


\section{Information about the authors:}

Adamchuk V.V.: vadimadamchuk@gmail.com; http://orcid.org/0000-0002-5009-7221; Department of Theory and Methodology of Sports, Vinnytsia Mykhailo Kotsiubynskyi State Pedagogical University, Ostrozhskyi St, 32, Vinnytsia, 21100 , Ukraine.

Shchepotina N.Yu.: shchepa@mbox.vn.ua; http://orcid.org/0000-0002-9507-3944; Department of Theory and Methodology of Sports, Vinnytsia Mykhailo Kotsiubynskyi State Pedagogical University, Ostrozhskyi St, 32, Vinnytsia, 21100 , Ukraine.

Kostiukevych V.M.: kostykevich.vik@gmail.com; http://orcid.org/0000-0002-6215-764X; Department of Theory and Methodology of Sports, Vinnytsia Mykhailo Kotsiubynskyi State Pedagogical University, Ostrozhskyi St, 32, Vinnytsia, 21100, Ukraine.

Vozniuk T.V.: TV_Vinnitsa@ukr.net; http://orcid.org/0000-0002-5951-7333; Department of Theory and Methodology of Sports, Vinnytsia Mykhailo Kotsiubynskyi State Pedagogical University, Ostrozhskyi St, 32, Vinnytsia, 21100, Ukraine.

Kulchytska I.A.: iravin82@gmail.com; orcid.org/0000-0001-6138-3015; Department of Theory and Methodology of Sports, Vinnytsia Mykhailo Kotsiubynskyi State Pedagogical University, Ostrozhskyi St, 32, Vinnytsia, 21100, Ukraine.

Didyk T.M.: ztat261@gmail.com; orcid.org/0000-0002-9129-2728; Department of Theory and Methodology of Sports, Vinnytsia Mykhailo Kotsiubynskyi State Pedagogical University, Ostrozhskyi St, 32, Vinnytsia, 21100, Ukraine.

Poliak V.A.: polyak989@gmail.com; orcid.org/0000-0002-1165-8831; Department of Theory and Methodology of Sports, Vinnytsia Mykhailo Kotsiubynskyi State Pedagogical University, Ostrozhskyi St, 32, Vinnytsia, 21100, Ukraine.

Cite this article as: Adamchuk, V., Shchepotina, N., Kostiukevych, V., Vozniuk, T., Kulchytska, I., Didyk, T., \& Poliak, V. (2021). Technological Aspects of Introduction of 8-Week Model at the Phase of Direct Training for Competitions of Highly Qualified Multi-Athletes in Track-And-Field Athletics. Teoriâ ta Metodika Fizičnogo Vihovannâ, 21(3), 200-210. https://doi.org/10.17309/tmfv.2021.3.03

Received: 14.06.2021. Accepted: 14.08.2021. Published: 25.09.2021

This work is licensed under a Creative Commons Attribution 4.0 International License (http://creativecommons.org/licenses/by/4.0). 